\title{
How Does Firm Characteristics Affect the Choices Dividend Payout? Evidence of Firms Listed in the Tunisian Stock Exchange
}

Ali Ahmadi*

Faculty of Economics and Management, Sfax, Tunisia

\begin{abstract}
This article investigates the relationship between some financial criteria and dividend payout policy choices of Tunisian firms' context. Specifically, we examine whether the determinant the firm characteristics affect the firms' policy choices to pay dividend. Overall, this research adds to our understanding of firms' dividend payout policy choices. It shows that the all included variables present strongest motivation to the dividends payout choice. The results also suggest that good financial performers are more likely to pay dividends more regularly. First, evidence on the relationship between the various types of financial characteristics and firms' choice of dividend payout frequencies should be useful to investors. Second, the findings of this study provide positive effects of firm performance, total of sales, firm value, and firm growth level on the dividend payout frequencies. The analysis indicates that dividend policy is related to firm value and there is a positive association between the firm's share pare price value and the dividend policy payout.
\end{abstract}

Keywords: Dividend payout; Firm performance; Total of sales; Firm value; Firm growth

\section{Introduction}

Starting from the study of Mozes and Rapaccioli [1] several research have examine the role played by the dividend announcements in the explanation of the inverse relation between the magnitude of the market reaction to earnings announcements and firm size. The authors find that if dividends are announced before the earnings announcement, no size effect exists. These findings imply that the information set conveyed by dividend announcements contains all information conveyed by sources that are available exclusively to investors in large firms. While, Taksar and Zhou [2] stipulate the implications that a dividend can have for a firm that has a moderate to high debt liability. Obaidan [3] provide a positive association between market efficiency and dividend levels in banks of Gulf region.

Refer to the research of Baker and Wurgler [4] the dividends seem to be considered one of the important indicators for investors in their decision process. Some investors look for dividend-paying stocks. In general, investors like dividends. Some previous studies identify that investors like to see the same amount of dividends or increase over time. Tse [5] suggests that dividends are used to signal firms' future prospects. Dividend payout patterns have been examined in some international business context and managers' behavioral aspects.

Porta et al. [6] argues that the association between agency theory, dividend policy and corporate governance. DeAngelo et al. [7] consider the dividend is an important indicator for investors, the author provide that the minority shareholders choose the payment dividend more than the reinvestment earnings. There are several studies that tested the association related the dividend paying pattern to the firm [8-13]. The purpose of present study is to examine effect of firms' characteristics on their decision dividend policy in Tunisia. We examine why firms choose to pay dividends continuously, intermittently, or not pay them. Few of studies tried to investigate this relationship using different financial measures and reached different conclusions. Specifically, the findings of our study provide evidence that firms with relatively larger debts tend to pay dividends less frequently than firms with smaller debts. It also makes a contribution to the body of knowledge about dividend payout.
The reminder of this study is recognized as follows: section 4 presents the literature background, section 5 the methodology; section 6 discusses the results; section 7 gives some conclusions.

\section{Background Literature}

One of important rights for investors is dividend. Jensen and Meckling [14] argue that managements tend to pursue self-interest on firms' management. This behavior will of course harm investors. According to several research the present research examines the relationship between dividend and firm valuation characteristics [1524]. Return on equity (ROE) is used as a proxy for a firm's financial performance, or more directly as a measure of a firm's ability to internally finance its funding needs. It is expected that the better a firm's financial performance, the more likely it is to pay dividends continuously. This argument leads to the following hypothesis:

H1. The firms with better financial performances are more likely to pay more dividends.

The higher market value to book value of the firm, the more frequent and consistent the pay dividends, as the firm is more likely to satisfy the investors in the stock markets.

H2. The higher market value to book value firm has, the more likely it pays dividends regularly.

The higher the sales are, the firm is more likely to pay dividends regularly, as it has more financial resources.

H3. The higher the firm's sales are, the more likely it pays dividends regularly.

*Corresponding author: Ali Ahmadi, Faculty of Economics and Management Sfax, Tunisia, E-mail: ahmadi2402@gmail.com

Received October 12, 2018; Accepted October 31, 2018; Published November 09, 2018

Citation: Ahmadi A (2018) How Does Firm Characteristics Affect the Choices Dividend Payout? Evidence of Firms Listed in the Tunisian Stock Exchange. J Account Mark 7: 297. doi: 10.4172/2168-9601.1000297

Copyright: @ 2018 Ahmadi A. This is an open-access article distributed under the terms of the Creative Commons Attribution License, which permits unrestricted use, distribution, and reproduction in any medium, provided the original author and source are credited. 
The higher the firm growth levels are, the more frequent and consistent the pay dividends, as the firm growth generate more earning and more dividends will be paid.

H4. The higher the firm growth is, the more likely it pays dividends regularly.

\section{Methodology}

\section{Sample and variables measurement}

The sample uses in this study contains annual reports for 87 companies listed in Tunisian stock exchange for the year 2016. The choice of firms was based on the availability of data. Similar to prior dividend studies we exclude financial firms and utilities because they are subject to specific requirements and our final sample contain 24 during the period 2010-2015 (168 observations firm-year). The sample of this research comprises 168 observations firms/year of non-financial firms listed in the Tunisian stock exchange that announces dividend payment during observation period for year 2010 to 2015 . We ran our empirical model using the static panel data technique which was estimated using least-square.

\section{Variables measurement}

The following Table 1 presents the descriptive statistics of this research.

The empirical model will be presented as follow:

DIVit $=\alpha 0+\alpha 1$ ROEit $+\alpha 2$ SALESit $+\alpha 3$ Pit $+\alpha 4$ FGRoWTHit + eit

\section{Analysis}

\section{Descriptive statistics}

Table 2, panel A and B provide descriptive statistics of for the dependent variables and independent variables and correlation coefficient matrix. The result indicates that the average dividend payout was .5141 per cent, with a minimum of 0 and a maximum of 76.19 percent. The value taken by firm performance varied between the min of $-2.36 \%$ and a maximum value of $20.46 \%$ with a mean of 8.9 percent that can reflect the importance of the level of financial performance. On average, 154506 thousand of Tunisian Dinar of total sales realized by firms during the period of our study. The variable share price $(\mathrm{P})$ has mean and standard deviation of 19.62423 and 48.03809 respectively. The average of firm growth value is $7 \%$ with a value of standard deviation is 17.67 with a minimum of -46 percent and a maximum of 89 percent.

Panel B of Table 2 presents the correlation matrix of the dependent and independent variables, from which, dividend payout level is positively correlated of all independent variables. All correlations have important coefficients value' which reflect the importance of the introduced value in the explanation of the independent value

The Table 2 shows that among the independent variables' correlations are relatively low, indeed Bryman and Cramer suggest that simple correlation between independent variables should not be considered harmful until they exceed 0.80 or 0.90 . This confirms that collinearity is not a problem for this model.

\section{Hypothesis testing}

In the remaining of the section, we will conduct a multivariate analysis taking into the simultaneous effect of all variables. The results show a significant explanatory power of the model $(\mathrm{R} 2=0.5689)$, we found that $56.89 \%$ of the variation in the dividend payout is explained by the explanatory variables, this significance also proved by fisher statistics with a value of $\mathrm{F}=13.56$ at 1 percent level of significance.

Eventually, study findings show there is a significant relationship between the dividend payout and financial performance, the result corroborate that expected and consistent with the theoretical statements although the positive effect of financial performance on the dividend payout level $(\mathrm{T}=2.02$ and $\mathrm{P}=0.089)$. According to the assumption that

\begin{tabular}{|c|c|c|c|}
\hline Label & Definition & Measurement \\
\hline DIV & Dividend payout & The dependent variable was dividend payout which was measured as dividend per share divided by & Dependent variable \\
\hline ROE & Firm performance & Firm ROE. \\
\hline SALES & The sales & Total of sales of the year \\
\hline P & Firm value & Firm share price \\
\hline FGRWTH & Firm growth & using the market value of equity/book value of equity as a proxy for firm growth \\
\hline
\end{tabular}

Table 1: Definition and measurement of variables.

\begin{tabular}{|c|c|c|c|c|c|}
\hline \multicolumn{6}{|c|}{ Panel A : descriptives statistiques } \\
\hline VARIABLE & Obs & Mean & Std. Dev. & Min & Max \\
\hline DIV & 168 & .5140643 & .3540665 & 0 & .761905 \\
\hline ROE & 168 & .0894194 & .142958 & -.0236972 & .204637 \\
\hline SALES & 168 & 15450.63 & 28005.29 & 3465.527 & 125936.3 \\
\hline $\mathbf{P}$ & 168 & 19.62423 & 48.03809 & .68 & 366.05 \\
\hline FGROWTH & 168 & .0739606 & .1769552 & -.4623857 & .8951006 \\
\hline \multicolumn{6}{|c|}{ Panel B : correlation matrix } \\
\hline & DIV & ROE & SALES & $\mathbf{P}$ & FGROWTH \\
\hline DIV & 1.0000 & & & & \\
\hline ROE & 0.3527 & 1.0000 & & & \\
\hline SALES & 0.7023 & 0.3240 & 1.0000 & & \\
\hline $\mathbf{P}$ & 0.7339 & 0.2572 & 0.3215 & 1.0000 & \\
\hline FGROWTH & 0.7626 & 0.4171 & 0.5262 & 0.4601 & 1.0000 \\
\hline
\end{tabular}

Table 2: Summary statistics for the dividend payout model. 
Citation: Ahmadi A (2018) How Does Firm Characteristics Affect the Choices Dividend Payout? Evidence of Firms Listed in the Tunisian Stock Exchange. J Account Mark 7: 297. doi: 10.4172/2168-9601.1000297

Page 3 of 3

\begin{tabular}{|c|c|c|c|c|c|}
\hline Variables & Predict sign & Coef. & Std. Err. & $t$ & $P>t$ \\
\hline Intercept & & .2293639 & .0286406 & 8.01 & 0.000 \\
\hline ROE & + & .0109899 & .00797921 & 2.02 & $0.089^{*}$ \\
\hline SALES & + & $1.54 \mathrm{e}-07$ & $1.62 \mathrm{e}-07$ & 0.95 & 0.345 \\
\hline $\mathbf{P}$ & + & .0059563 & .0009011 & 6.61 & $0.000^{* * *}$ \\
\hline FGROWTH & + & 1.948276 & .1723086 & 11.31 & $0.000 * * *$ \\
\hline $\mathbf{R}^{2}$ & 0.5689 & & & & \\
\hline Adj $R^{2}$ & 0.5632 & & & & \\
\hline$F(4,163)$ & 13.560 & & & & \\
\hline Prob > F & 0.0000 & & & & \\
\hline
\end{tabular}

Where ${ }^{*},{ }^{* *}$ and ${ }^{* * *}$ indicate significance at the $0.01,0.05$ and 0.10 levels, respectively

Table 3: Regression results.

stimulates a positive association between the total of sales and their level of dividend payout, we find a positive sign but no significant effect $(\mathrm{T}=0.95$ and $\mathrm{P}=0.345)$.

This analysis shows that there is a statistically significant coefficient concerning the variable share price, the findings confirm the expected hypothesis and the results of previous studies, and show that the share price value has a positive impact on the firm payout dividend level $(\mathrm{T}=$ 6.61 ) in $1 \%$ level of significance $\mathrm{P}=0.000$.

As could be expected, the results show that the coefficient related to the firm growth support the hypothesis expected. Indeed, a statistics $\mathrm{T}=11.31$ with a level of significance $\mathrm{P}=0.000$ reported to support the results of previous studies that have proven that a high level of firm growth improves the dividend payout (Table 3 ).

\section{Conclusion}

We investigated the effect of firm valuation characteristics on their dividend payouts level. The empirical results provide effects of all independent variables on the dividend payouts. The higher the percentage of financial performance, the greater is the incentives to monitor managers and to ensure that returns on investments are realized. The higher the percentages of financial performance, the higher are the dividends received by shareholder. Further analysis has shown that total of sales has a positive effect on the dividend payouts. Also, price share may have more incentives to tunnel resources to their affiliated firms. Going deeper, looking at the effect on dividends and firm growth provided consistent results. There was shown to be a positive effect of firm growth level on dividend payouts. Our findings have several policy implications. First, investors should consider several firm valuation characteristics before making their investment decisions. This study has found that all independent variables have positive effects on dividend payouts. Therefore, higher values are taken by independent variables higher the dividend payout.

\section{References}

1. Mozes H, Rapaccioli D (1995) The relation among dividend policy, firm size, and the information content of earnings announcements. J Financ Res 18: 75-88.

2. Taksar M, Zhou X (1998) Optimal risk and dividend control for a company. Insur Math Econ 22: 105-122.

3. Obaidan A (2008) Information content of dividends in the commercial banking industry of emerging markets. Int Res J Finance Econ 17: 105-116.

4. Baker M, Wurgler J (2004) A catering theory of dividends. J of Finance 59 1125-1165.
5. Tse C (2005) Use dividends to signal or not: An examination of the UK dividend payout patterns. Manage Finance 31: 12-22.

6. Porta R, Silanes F, Shleifer A, Vishny R (2000) Agency problems and dividend policies around the world. J Finance 55: 1-33.

7. DeAngelo H, DeAngelo L, Stulz R (2006) Dividend policy and the earned/ contributed capital mix: a test of the life-cycle theory. J Financ Econ 81: 227-254.

8. Fama E, French K (2001) Disappearing dividends: Changing firm characteristics or lower propensity to pay? J Financ Econ 60: 3-44.

9. Denis DJ, Osobov I (2008) Why do firms pay dividends? International evidence on determinants of dividend policy. J Financ Econ 89: 62-82.

10. Ferris SP, Sen N, Unlu E (2009) An international analysis of dividend payment behavior. J Bus Finance Account 36: 496-522.

11. Wang M, Ke M, Liu D, Huang Y (2011) Dividend policy and the life cycle hypothesis: Evidence from Taiwan. Int J Bus Finance Res 5: 33-52.

12. Byrne J, O'Connor T (2017) Creditor rights, culture and dividend payout policy. $\mathrm{J}$ Multinational Financ Manage 39: 60-77.

13. Adhikari KB, Agrawal A (2018) Peer influence on payout policies. J Corporate Finance 48: 615-637.

14. Jensen M, Meckling W (1976) Theory of the firm: managerial behavior, agency cost and ownership structure. J Financ Econ 3: 305-360.

15. Shin H, Stulz R (2000) Firm value, risk, and growth opportunities. Working Paper No. 7808. NBER

16. Grullon G, Michaely R (2002) Dividends, share repurchases, and the substitution hypothesis. J Finance 57: 1649-1684.

17. Hsieh J, Wang Q, Baker HK (2009) Stock Repurchases: Theory and Evidence Pp: 46.

18. Twu M (2010) Prior payment status and the likelihood to pay dividends: International evidence. Financ Rev 45: 785-802.

19. Yarram SR, Dollery B (2015) Corporate governance and financial policies: Influence of board characteristics on the dividend policy of Australian firms. Manage Finance 41: 267-285.

20. Baker HK, Weigand R (2015) Corporate dividend policy revisited. Manage Finance 41: 126-144

21. Hauser R, Thornton J (2017) Dividend policy and corporate valuation. Manage Finance 43: 663-678

22. Bäuerle N, Jaśkiewicz A (2017) Optimal dividend payout model with risk sensitive preferences. Insur: Math Econ 73: 82-93.

23. Jiang F, Ma Y, Shi B (2017) Stock liquidity and dividend payouts. J Corporate Finance 42: 295-314

24. Karpavičius S, Yu F (2018) Dividend premium: Are dividend-paying stocks worth more? Int Rev Financ Anal 56: 112-126. 